Article

\title{
Transesterification of glycerol with dimethyl carbonate over calcined Ca-Al hydrocalumite
}

\author{
Liping Zheng a, Shuixin Xia a, Xiuyang Lu b , Zhaoyin Hou a,* \\ ${ }^{a}$ Key Lab of Applied Chemistry of Zhejiang Province, Department of Chemistry, Zhejiang University, Hangzhou 310028, Zhejiang, China \\ ${ }^{\mathrm{b}}$ Department of Chemical and Biological Engineering, Zhejiang University, Hangzhou 310027, Zhejiang, China
}

A R T I C L E I N F O

Article history:

Received 23 March 2015

Accepted 16 May 2015

Published 20 October 2015

\section{Keywords:}

Glycerol

Dimethyl carbonate

Transesterification

Glycerol carbonate

Calcium-aluminum hydrocalumite

\section{A B S T R A C T}

A series of Ca-Al hydrocalumite with different $\mathrm{Ca} / \mathrm{Al}$ ratios (1-6) were synthesized and used in the transesterification of glycerol with dimethyl carbonate (DMC) to glycerol carbonate (GC) under mild conditions. The calcined Ca-Al hydrocalumites were active with a selectivity toward GC that reached $97 \%$ at $93 \%$ conversion of glycerol over the sample with $\mathrm{Ca} / \mathrm{Al}=2$ at $70^{\circ} \mathrm{C}, 3 \mathrm{~h}$, and $\mathrm{DMC} /$ glycerol $=$ 3. The glycerol conversion depended mainly on the proportion of strong basic sites in the calcined $\mathrm{Ca}-\mathrm{Al}$ catalysts. The $\mathrm{Ca}_{12} \mathrm{Al}_{14} \mathrm{O}_{33}$ phase in the calcined catalysts was stable, but $\mathrm{CaO}$ was lost in recycle experiments and thus brought deactivation.

(C) 2015, Dalian Institute of Chemical Physics, Chinese Academy of Sciences. Published by Elsevier B.V. All rights reserved.

\section{Introduction}

Biodiesel is an important renewable biofuel which can be produced from animal fat and vegetable oil via transesterification. The application of biodiesel can help reduce the dependence on fossil energy. Glycerol is a byproduct in the production of biodiesel, and the rapidly rising production of biodiesel leads to a large surplus of glycerol. The catalytic conversion of glycerol to valuable products has become a hot research topic [1-4]. Several products, such as propanediols [5-10], dihydroxyacetone [11-13], acrolein [14-16], and glycerol carbonate (GC) [17-19], can be synthesized from glycerol. Among these products, GC is one of the most attractive derivatives of glycerol because of its high reactivity with alcohols, amines, carboxylic acids, ketones, and isocyanates, which can yield a wide range of valuable products [20]. GC itself can be used as a solvent in NMR analysis and organic synthesis [20]. In addition, it has been reported that GC is an important alternative solvent in lithium batteries, cosmetics, surfactants, and polymer synthesis [20]. Several routes, such as phosgenation between glycerol and phosgene [21], direct carboxylation of glycerol with $\mathrm{CO}_{2}[22,23]$, and the glycerolysis of urea [24-28], have been proposed for the production of GC from glycerol. Among these, the direct reaction between glycerol and $\mathrm{CO}_{2}$ is an attractive route, but it must be performed at high pressure and the yield of GC is low [29,30].

Transesterification of glycerol with dimethyl carbonate (DMC) is also an attractive way to produce GC under mild conditions [17,18]. It was reported that $\mathrm{K}_{2} \mathrm{CO}_{3}$ [31], $\mathrm{CaO}$ [32], K-zeolite derived from coal fly ash [33], $\mathrm{Mg} / \mathrm{Zr} / \mathrm{Sr}$ [34] and $\mathrm{Mg} / \mathrm{Al} / \mathrm{Zr}$ [35] mixed oxides were effective for this reaction. The rate of this reaction depended on the basicity of the catalyst [36], but the selectivity of GC decreased when a strong base (such as $\mathrm{NaOH}, \mathrm{KOH}$, and $\mathrm{K}_{2} \mathrm{CO}_{3}$ ) was used because of the for-

\footnotetext{
* Corresponding author. Tel/Fax: +86-571-88273283; E-mail: zyhou@zju.edu.cn

This work was supported by the National Natural Science Foundation of China $(21473155,21273198,21073159)$ and the Zhejiang Provincial Natural Science Foundation (LZ12B03001).

DOI: 10.1016/S1872-2067(15)60915-9 | http://www.sciencedirect.com/science/journal/18722067 | Chin. J. Catal., Vol. 36, No. 10, October 2015
} 
mation of glycidol [37]. More recently, Liu et al. [19] disclosed that the activity of transition metal doped hydrotalcites (HT-M) for the transesterification between glycerol and DMC depended on the surface density of basic sites.

Hydrocalumite is a layered double hydroxide (LDH) with a well ordered Ca-Al distribution in the hydroxide layers, while the anions and water are highly ordered in the interlayer spaces $[38,39]$. The calcined hydrocalumite-like compound mainly contains $\mathrm{Ca}_{12} \mathrm{Al}_{14} \mathrm{O}_{33}$ and $\mathrm{CaO}$, and it shows strong basicity in $\mathrm{CO}_{2}$ adsorption [40] and in the production of biodiesel via transesterification $[41,42]$. In this work, a series of Ca-Al hydrocalumite with different $\mathrm{Ca} / \mathrm{Al}$ ratios (1-6) were synthesized and used in the transesterification of glycerol with DMC to GC under mild conditions. The activity and structure of the calcined hydrocalumite were discussed.

\section{Experimental}

\subsection{Catalyst preparation}

Ca-Al hydrocalumite $(\mathrm{Ca} / \mathrm{Al}=1-6)$ was prepared by a conventional coprecipitation method. $\mathrm{CaCl}_{2}(12.5-75 \mathrm{mmol})$ and $\mathrm{AlCl}_{3} \cdot 6 \mathrm{H}_{2} \mathrm{O}(12.5 \mathrm{mmol})$ were dissolved in $75 \mathrm{~mL}$ deionized water (solution A) [43]. Solution B was an aqueous solution of $2 \mathrm{~mol} / \mathrm{L} \mathrm{NaOH}$. Solutions A and B were simultaneously added to a $250 \mathrm{~mL}$ three-necked flask under a purified $\mathrm{N}_{2}$ flow at 30 ${ }^{\circ} \mathrm{C}$ with the $\mathrm{pH}$ of the mixture controlled at 11 during the addition [44]. The resulting suspension was filtered and washed thoroughly with deionized water until the $\mathrm{pH}$ of the filtrate reached about 7.0. The precipitate was dried at $110{ }^{\circ} \mathrm{C}$ overnight and calcined at $400-1000{ }^{\circ} \mathrm{C}$ for $4 \mathrm{~h}$ under a purified $\mathrm{N}_{2}$ flow. The composition of the $\mathrm{Ca}-\mathrm{Al}$ hydrocalumites was determined using inductively coupled plasma-atomic emission spectroscopy (ICP-AES). The obtained Ca-Al hydrocalumite was denoted as $\mathrm{Ca}_{x} \mathrm{Al}-\mathrm{y}$, in which $x$ represented the molar ratio of $\mathrm{Ca} / \mathrm{Al}$ and $y$ denoted the calcination temperature.

\subsection{Catalyst characterization}

X-ray diffraction (XRD) patterns were collected on a Rigaku D/MAX-2500 diffractometer with a $2 \theta$ range of $5^{\circ}-80^{\circ}$ using $\mathrm{Cu}$ $K_{\alpha}$ radiation $(\lambda=0.15406 \mathrm{~nm})$. Thermogravimetric differential scanning (TG-DSC) analysis of the samples from room temperature to $800{ }^{\circ} \mathrm{C}$ was carried out on a Netzsch STA409 thermobalance system using a heating rate of $10{ }^{\circ} \mathrm{C} / \mathrm{min}$ under $\mathrm{N}_{2}$ nitrogen flow. Scanning electron microscopic (SEM) images were obtained on a Leo Evo Series SEM (VP 1430, Germany). Samples were coated with gold to avoid charging. Analysis was carried out at an accelerating voltage of $15 \mathrm{kV}$. The $\mathrm{N}_{2}$ adsorption-desorption isotherm was measured at $-196{ }^{\circ} \mathrm{C}$ using a TriStar II analyzer after pretreatment of the sample at $150{ }^{\circ} \mathrm{C}$ for $10 \mathrm{~h}$. The basicity of the catalyst was determined by temperature-programmed desorption of $\mathrm{CO}_{2}\left(\mathrm{CO}_{2}\right.$-TPD). In this experiment, the sample was first treated in $\mathrm{Ar}$ at $600{ }^{\circ} \mathrm{C}$ for 30 min, cooled to $50{ }^{\circ} \mathrm{C}$ and exposed to $20 \% \mathrm{CO}_{2}(50 \mathrm{~mL} / \mathrm{min}, \mathrm{Ar}$ in balance) for $30 \mathrm{~min}$. It was then purged with $\mathrm{Ar}$ for $1 \mathrm{~h}$ at $100{ }^{\circ} \mathrm{C}$ and heated linearly at $15{ }^{\circ} \mathrm{C} / \mathrm{min}$ to $800{ }^{\circ} \mathrm{C}$ in 50
$\mathrm{mL} / \mathrm{min} \mathrm{Ar} . \mathrm{CO}_{2}(\mathrm{~m} / \mathrm{e}=44)$ in the effluent was recorded continuously as a function of temperature.

\subsection{Catalytic reaction}

Measured amounts of DMC (45 mmol) and glycerol (45 mmol) were mixed in a $10 \mathrm{~mL}$ round bottomed glass reactor fitted with a magnetic stirrer and a reflux condenser. The mixture was first heated under stirring to $70{ }^{\circ} \mathrm{C}$, and the catalyst $(0.15 \mathrm{~g})$ was added to start the reaction. After reacting for $3 \mathrm{~h}$, the solid catalyst was removed by centrifugation, and the supernatant liquid was analyzed using a gas chromatograph (Shimadzu, 14B) equipped with a 30-m capillary column (DB-WAX $52 \mathrm{CB}, \mathrm{USA}$ ) and a flame ionization detector. All products detected in the liquid were identified by a gas chromatography-mass spectrometry system (GC-MS, Agilent 6890) and quantified by an external calibration method. The product selectivity was calculated on a carbon basis.

\section{Results and discussion}

\subsection{Catalyst characterization}

Figure 1 shows the XRD patterns of the Ca-Al samples. All the diffraction peaks of the (002), (004), (010), and (006) planes of hydrocalumite $\left(\mathrm{Ca}_{4} \mathrm{Al}_{2} \mathrm{O}_{6} \mathrm{Cl}_{2} \cdot 10 \mathrm{H}_{2} \mathrm{O}\right.$, JCPDS 00-0310245) $[44,45]$ were detected. This result indicates that a hydrocalumite-like compound formed and a high degree of crystallinity was detected in all those samples with $\mathrm{Ca} / \mathrm{Al}=2-6$. On the other hand, $\mathrm{Al}(\mathrm{OH})_{3}$ (JCPDS 00-033-0018) was formed in $\mathrm{Ca}_{1} \mathrm{Al}$ due to the high content of $\mathrm{Al}[40]$.

Figure 2 shows typical SEM images of the Ca-Al hydrocalumites. Solid Ca-Al lamellas were formed in all samples. A clear image of separated lamellas was detected in $\mathrm{Ca}_{2} \mathrm{Al}$ and $\mathrm{Ca}_{3} \mathrm{Al}$. The platelet in $\mathrm{Ca}_{6} \mathrm{Al}$ was smaller and an amorphous solid (in white circle) was formed in Ca1Al. The peony-shaped crystal in $\mathrm{Ca}_{2} \mathrm{Al}$ showed the rough outline of hydrocalumite. The high resolution image of this sample is shown in Fig. 2(c). We can also see some "rosette" particles in Ca3Al (Fig. 2(d)) [46].

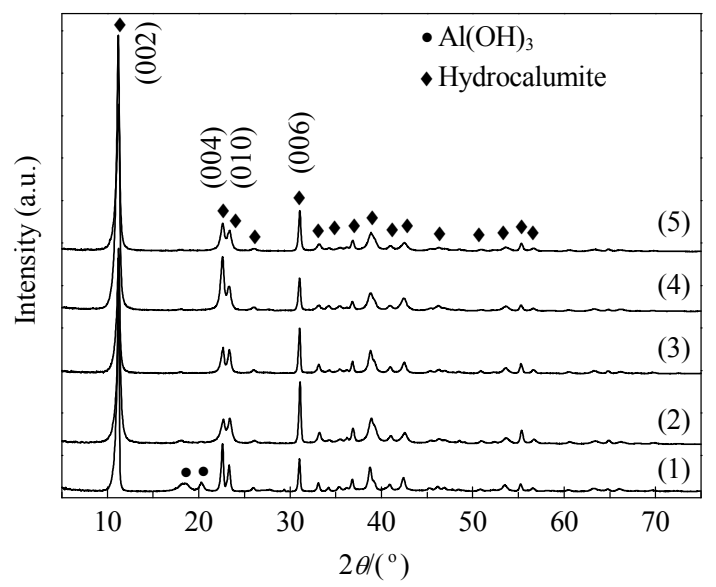

Fig. 1. XRD patterns of fresh $\mathrm{Ca}-\mathrm{Al}$ hydrocalumite with different $\mathrm{Ca} / \mathrm{Al}$ ratios. (1) $\mathrm{Ca}_{1} \mathrm{Al}$; (2) $\mathrm{Ca}_{2} \mathrm{Al}$; (3) $\mathrm{Ca}_{3} \mathrm{Al}$; (4) $\mathrm{Ca}_{4} \mathrm{Al}$; (5) $\mathrm{Ca}_{6} \mathrm{Al}$. 


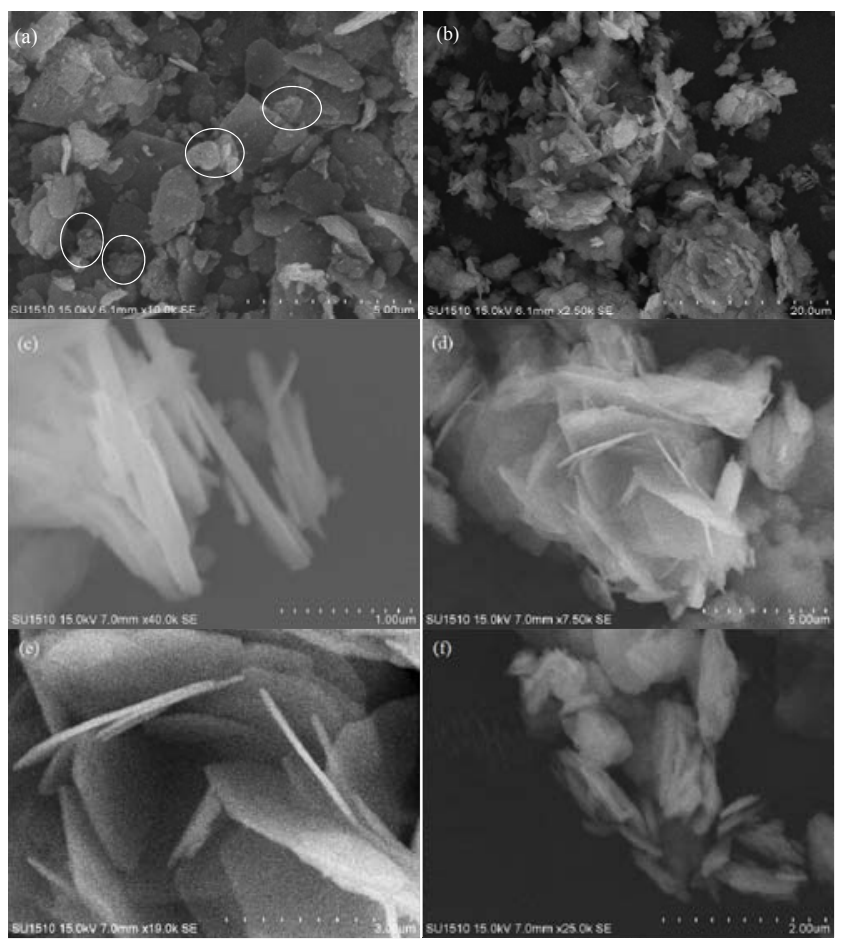

Fig. 2. SEM images of fresh Ca-Al hydrocalumite. (a) $\mathrm{Ca}_{1} \mathrm{Al}$; (b, c) $\mathrm{Ca}_{2} \mathrm{Al}$; (d, e) $\mathrm{Ca}_{3} \mathrm{Al}$; (f) $\mathrm{Ca}_{6} \mathrm{Al}$.

Figure 3 presents the TG-DSC curves of the hydrocalumite ( $\left.\mathrm{Ca}_{2} \mathrm{Al}\right)$. The TG curve indicated that there were four stages of weight losses at 50-152, 265-329, 420-494, and 600-750 ${ }^{\circ} \mathrm{C}$. The first stage was attributed to the removal of adsorbed water, the second stage was due to the loss of bound water or chloride in the interlayer of the hydrocalumite [47], and the third and the fourth stage was attributed to the further removal of hydroxyl groups. At the same time, an exothermic peak was detected at $786{ }^{\circ} \mathrm{C}$ without obvious weight loss, which was attributed to the decomposition of layered $\mathrm{Ca}_{4} \mathrm{Al}_{2} \mathrm{O}_{7}$ to $\mathrm{Ca}_{12} \mathrm{Al}_{14} \mathrm{O}_{33}$ and $\mathrm{CaO}[48,49]$.

Figure 4 shows the XRD patterns of Ca-Al hydrocalumite calcined at different temperatures for $4 \mathrm{~h}$. The peaks assigned to the (002), (004), and (006) planes of hydrocalumite disappeared with the loss of water, chloride, and hydroxide after

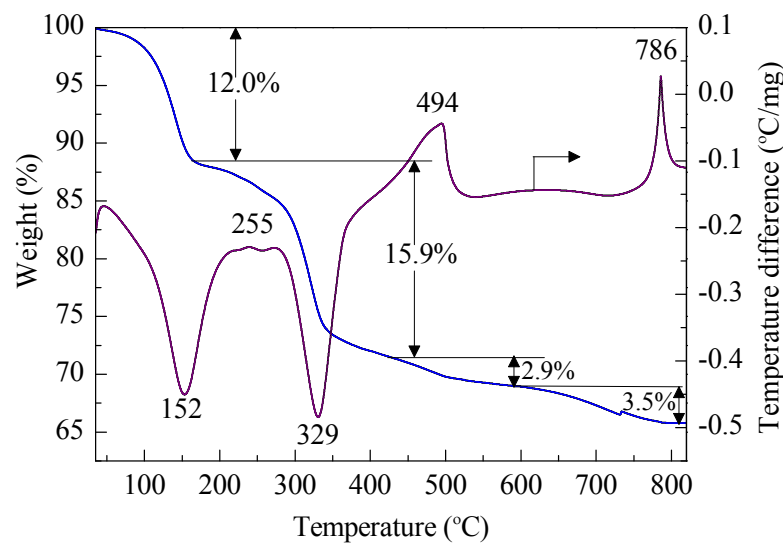

Fig. 3. TG-DSC curves of the hydrocalumite $\left(\mathrm{Ca}_{2} \mathrm{Al}\right)$.

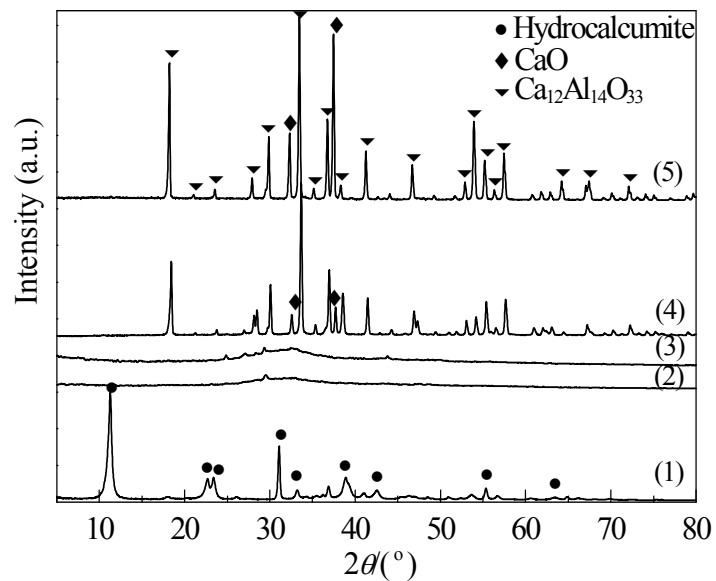

Fig. 4. XRD patterns of synthesized Ca-Al hydrocalumite $\left(\mathrm{Ca}_{2} \mathrm{Al}\right)(1)$ and calcined at $400{ }^{\circ} \mathrm{C}(2), 600{ }^{\circ} \mathrm{C}(3), 800^{\circ} \mathrm{C}(4)$, and $1000^{\circ} \mathrm{C}(5)$.

calcination at $400{ }^{\circ} \mathrm{C}$. A broad peak at $25^{\circ}-35^{\circ}$ in the sample calcined at $600{ }^{\circ} \mathrm{C}$ was attributed to the formation of amorphous $\mathrm{CaO}$ due to the partial collapse of layered structure. Calcination above $800{ }^{\circ} \mathrm{C}$ led to the generation of mayenite $\mathrm{Ca}_{12} \mathrm{Al}_{14} \mathrm{O}_{33}$ (JCPDS 00-048-1882) [39,50]. These results fitted well the TG-DSC analysis.

Figure 5 shows the typical SEM image of hydrocalumite ( $\mathrm{Ca}_{2} \mathrm{Al}$ ) calcined at $800{ }^{\circ} \mathrm{C}$ for $4 \mathrm{~h}$. It is obvious that the layered structure was broken and the lamellas had accumulated as one hard stone.

Figure 6 presents the $\mathrm{CO}_{2}$-TPD profiles of $\mathrm{Ca}_{2} \mathrm{Al}$ hydrocalumite calcined at different temperatures. The desorption profiles were deconvoluted to incorporate two kinds of basic sites. The first $\left(250\right.$ to $600{ }^{\circ} \mathrm{C}$ ) was ascribed to the desorption of $\mathrm{CO}_{2}$ adsorbed on the surface of LDH lamella and Lewis basic sites of Ca in the LDH framework $[49,50]$. The proportion of these basic sites was higher in the samples calcined at 400 and $600^{\circ} \mathrm{C}$. The second peak (desorbed above $600{ }^{\circ} \mathrm{C}$ ) was attributed to the desorption of $\mathrm{CO}_{2}$ adsorbed on $\mathrm{CaO}$ and $\mathrm{Ca}_{12} \mathrm{Al}_{14} \mathrm{O}_{33}$. The proportion of these basic sites was calculated and summarized in Table 1. The calculated amount of total basic sites decreased along with the surface area when the calcination temperature was increased from 400 to $1000^{\circ} \mathrm{C}$. But it is interesting to note that the proportion of strong basic sites reached a maximum value $(56.9 \mu \mathrm{mol} / \mathrm{g})$ when the sample was calcined at $800^{\circ} \mathrm{C}$.

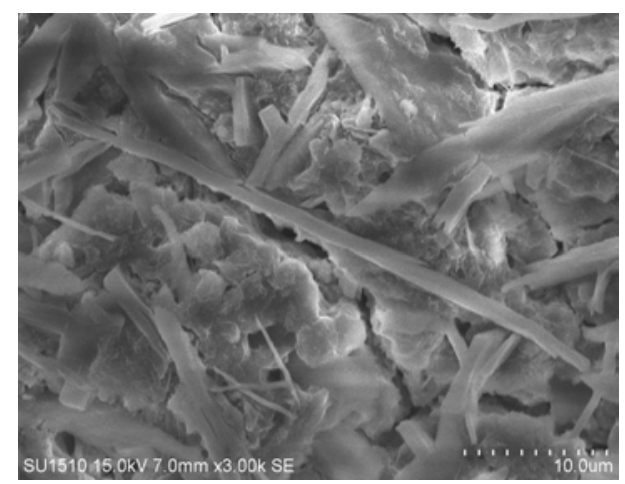

Fig. 5. SEM image of $\mathrm{Ca}_{2} \mathrm{Al}$ hydrocalumite calcined at $800^{\circ} \mathrm{C}$ for $4 \mathrm{~h}$. 


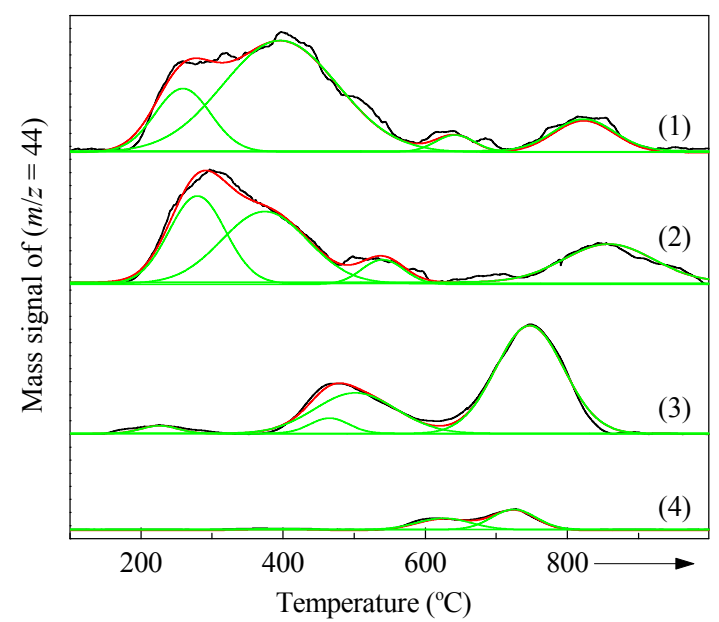

Fig. 6. $\mathrm{CO}_{2}$ - TPD profiles of $\mathrm{Ca}_{2} \mathrm{Al}$ hydrocalumite calcined at $400{ }^{\circ} \mathrm{C}(1)$, $600^{\circ} \mathrm{C}(2), 800{ }^{\circ} \mathrm{C}(3)$, and $1000^{\circ} \mathrm{C}(4)$.

Table 1

Surface area and basicity of hydrocalumite $\left(\mathrm{Ca}_{2} \mathrm{Al}\right)$ calcined at different temperatures.

\begin{tabular}{lcccc}
\hline \multirow{2}{*}{$t /{ }^{\circ} \mathrm{C}$} & $\begin{array}{c}S_{\mathrm{BET}} \\
\left(\mathrm{m}^{2} / \mathrm{g}\right)\end{array}$ & \multicolumn{2}{c}{ Desorbed $\mathrm{CO}_{2}{ }^{\mathrm{a}}(\mu \mathrm{mol} / \mathrm{g})$} & $\begin{array}{c}\text { Basicity density of strong } \\
\text { Bannnn} \\
\text { basic sites }{ }^{\mathrm{b}}\left(\mu \mathrm{mol} / \mathrm{m}^{2}\right)\end{array}$ \\
\hline 400 & 13.7 & 155.4 & 20.7 & 1.5 \\
600 & 6.4 & 53.8 & 24.0 & 3.7 \\
800 & 5.5 & 28.4 & 56.9 & 10.3 \\
1000 & 1.6 & 0.6 & 13.1 & 8.2 \\
\hline
\end{tabular}

${ }^{\text {a }}$ Determined by $\mathrm{CO}_{2}$-TPD.

b Calculated by desorbed $\mathrm{CO}_{2}$ at $>600^{\circ} \mathrm{C} / S_{\text {BET. }}$.

\subsection{Catalytic reactions}

\subsubsection{Transesterification of glycerol over $\mathrm{Ca}_{2} \mathrm{Al}$ calcined at different temperatures}

Figure 7 shows the activity of $\mathrm{Ca}_{2} \mathrm{Al}$ hydrocalumite calcined at different temperatures for the transesterification reaction between glycerol and DMC at $70{ }^{\circ} \mathrm{C}$. The conversion of glycerol increased steadily from $27 \%$ to $75 \%$ when the calcination temperature rose from 400 to $800{ }^{\circ} \mathrm{C}$, and the selectivity of GC was higher than $97 \%$. The conversion of glycerol and selectivity of GC over the hydrocalumite calcined at $1000{ }^{\circ} \mathrm{C}$ decreased to

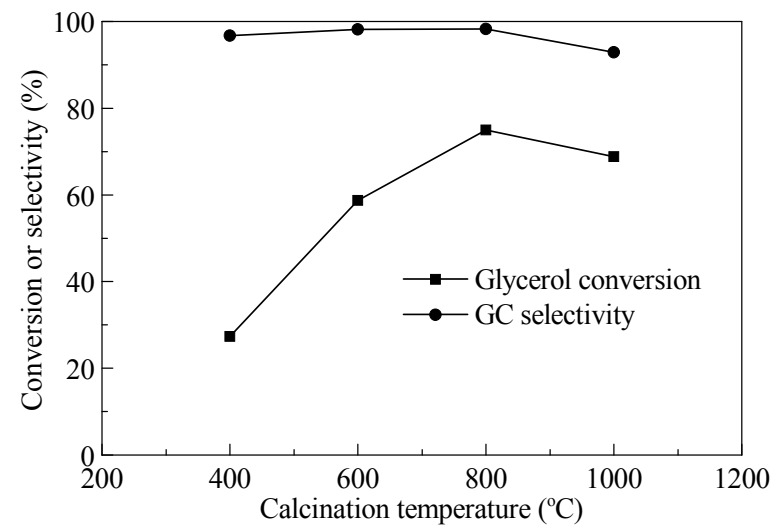

Fig. 7. Transesterification of glycerol over $\mathrm{Ca}_{2} \mathrm{Al}$ prepared at different calcination temperatures. Reaction conditions: calcined $\mathrm{Ca}_{2} \mathrm{Al} 0.15 \mathrm{~g}$, glycerol $45 \mathrm{mmol}$, DMC $45 \mathrm{mmol}, 70{ }^{\circ} \mathrm{C}, 3 \mathrm{~h}$.
$63 \%$ and $92 \%$, respectively. These results indicated that calcined $\mathrm{Ca}-\mathrm{Al}$ hydrocalumites were effective catalysts for the transesterification reaction between glycerol and DMC, and strong basic sites were more active. The conversion of glycerol depended mainly on the proportion of strong basic sites (Table 1).

\subsubsection{Transesterification of glycerol over $\mathrm{Ca}_{x} \mathrm{Al}$ with different Ca/Al ratios}

Table 2 summarizes the activity of calcined (at $800{ }^{\circ} \mathrm{C}$ for 4 h) $\mathrm{Ca}_{x} \mathrm{Al}$ hydrocalumites with different $\mathrm{Ca} / \mathrm{Al}$ ratios for the transesterification reaction between glycerol and DMC at $70{ }^{\circ} \mathrm{C}$. The conversion of glycerol increased from $51 \%$ to $75 \%$ when the $\mathrm{Ca} / \mathrm{Al}$ ratio increased from 1 to 2 . The selectivity to GC remained higher than $96 \%$. However, the conversion of glycerol and the selectivity of GC decreased slowly on the samples with higher $\mathrm{Ca} / \mathrm{Al}$ ratios $(>3)$. The characterization disclosed that $\mathrm{Ca}_{12} \mathrm{Al}_{14} \mathrm{O}_{33}$ and $\mathrm{CaO}$ were formed in the calcined (at $800{ }^{\circ} \mathrm{C}$ for $4 \mathrm{~h}$ ) $\mathrm{Ca} / \mathrm{Al}$ hydrocalumites. Although $\mathrm{CaO}$ can catalyze this reaction, the selectivity of the desired product was low (62\%). At the same time, $\mathrm{CaO}$ can combine with glycerol and DMC as $\mathrm{Ca}\left(\mathrm{C}_{3} \mathrm{H}_{7} \mathrm{O}_{3}\right)\left(\mathrm{OCO}_{2} \mathrm{CH}_{3}\right)$ during the reaction [51]. On the basis of these results, we conclude that $\mathrm{Ca}_{12} \mathrm{Al}_{14} \mathrm{O}_{33}$ derived from calcined $\mathrm{Ca} / \mathrm{Al}$ hydrocalumite is more selective to GC.

\subsubsection{Influence of DMC/glycerol molar ratio on the conversion of glycerol}

Table 3 summarizes the activity of calcined hydrocalumite $\left(\mathrm{Ca}_{2} \mathrm{Al}\right.$, at $800{ }^{\circ} \mathrm{C}$ for $4 \mathrm{~h}$ ) for the transesterification reaction between glycerol and $\mathrm{DMC}$ at $70{ }^{\circ} \mathrm{C}$ with different feed composition (DMC/glycerol ratio). The conversion of glycerol reached 93\% when the DMC/glycerol molar ratio was 3. Further increase in the amount of DMC in the feed did not promote the conversion of glycerol because the intersolubility of DMC and glycerol is low.

Table 2

Activity of calcined hydrocalumite with different $\mathrm{Ca} / \mathrm{Al}$ ratios.

\begin{tabular}{lccc}
\hline Catalyst & $\begin{array}{c}\text { Glycerol conversion } \\
(\%)\end{array}$ & $\begin{array}{c}\text { GC selectivity } \\
(\%)\end{array}$ & $\begin{array}{c}\text { Glycidol selectivity } \\
(\%)\end{array}$ \\
\hline Pure $\mathrm{CaO}$ & 60 & 62 & 38 \\
$\mathrm{Ca}_{1} \mathrm{Al}$ & 51 & 96 & 4 \\
$\mathrm{Ca}_{2} \mathrm{Al}$ & 75 & 98 & 2 \\
$\mathrm{Ca}_{3} \mathrm{Al}$ & 69 & 93 & 7 \\
$\mathrm{Ca}_{4} \mathrm{Al}$ & 67 & 94 & 6 \\
$\mathrm{Ca}_{6} \mathrm{Al}$ & 66 & 91 & 9 \\
\hline
\end{tabular}

Reaction conditions: catalyst $\left(\mathrm{Ca}_{x} \mathrm{Al}\right.$ hydrocalumite calcined at $800{ }^{\circ} \mathrm{C}$ for $4 \mathrm{~h}$ ) $0.15 \mathrm{~g}$, glycerol $45 \mathrm{mmol}$, DMC $45 \mathrm{mmol}, 70^{\circ} \mathrm{C}, 3 \mathrm{~h}$.

Table 3

Transesterification of glycerol as a function of DMC/glycerol molar ratio.

\begin{tabular}{lccc}
\hline $\begin{array}{l}\text { DMC/ } \\
\text { glycerol }\end{array}$ & $\begin{array}{c}\text { Glycerol conversion } \\
(\%)\end{array}$ & $\begin{array}{c}\text { GC selectivity } \\
(\%)\end{array}$ & $\begin{array}{c}\text { Glycidol selectivity } \\
(\%)\end{array}$ \\
\hline 1 & 75 & 98 & 2 \\
2 & 84 & 97 & 3 \\
3 & 93 & 97 & 3 \\
4 & 68 & 98 & 2 \\
\hline
\end{tabular}

Reaction conditions: catalyst $\left(\mathrm{Ca}_{2} \mathrm{Al}\right.$ hydrocalumite calcined at $800{ }^{\circ} \mathrm{C}$ for $4 \mathrm{~h}$ ) $0.15 \mathrm{~g}$, glycerol $45 \mathrm{mmol}, 70^{\circ} \mathrm{C}, 3 \mathrm{~h}$. 


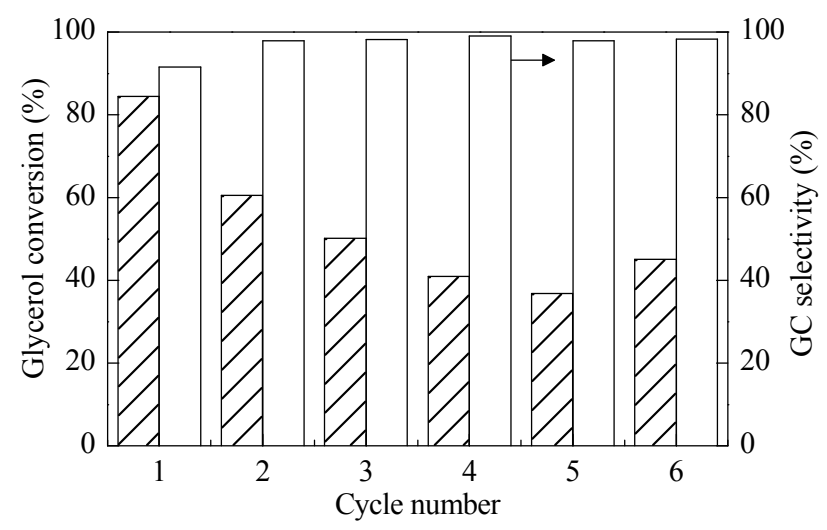

Fig. 8. Performance of the recycled catalyst $\left(\mathrm{Ca}_{2} \mathrm{Al}\right)$. Reaction conditions: glycerol $45 \mathrm{mmol}$, DMC $90 \mathrm{mmol}, 70^{\circ} \mathrm{C}, 3 \mathrm{~h}$.

\subsubsection{Recycling of the catalyst}

Figure 8 presents the performance of a recycled catalyst $\left(\mathrm{Ca}_{2} \mathrm{Al}\right)$ for the transesterification reaction between glycerol and DMC at $70{ }^{\circ}$. The reused catalyst was collected and dried in vacuum for several hours. The conversion of glycerol decreased from $84 \%$ to $38 \%$ as the recycle number increased. XRD analysis of the 6-time recycled catalyst disclosed that the crystalline structure of $\mathrm{Ca}_{12} \mathrm{Al}_{14} \mathrm{O}_{33}$ in the recycled catalyst was similar to that of the fresh calcined sample, but the $\mathrm{CaO}$ crystalline phase had disappeared (Fig. 9). ICP analysis also confirmed that the content of $\mathrm{Ca}^{2+}$ decreased from $12.2 \mathrm{mmol} / \mathrm{g}$ (in fresh catalyst) to $9.64 \mathrm{mmol} / \mathrm{g}$ (in the 6-times recycled catalyst). These results indicated that the deactivation of the calcined $\mathrm{Ca}-\mathrm{Al}$ hydrocalumite was due to the leaching of $\mathrm{Ca}$ and the loss of catalyst during the recycle experiment (the weight of the catalyst decreased from the initial 0.150 to $0.075 \mathrm{~g}$ after 6 recycles).

\section{Conclusions}

Ca-Al hydrocalumite $(\mathrm{Ca} / \mathrm{Al}=2-6)$ with high crystallinity was synthesized by a conventional coprecipitation method in $\mathrm{N}_{2}$ atmosphere. Calcined Ca-Al hydrocalumite was an effective catalyst for the transesterification of glycerol with DMC and

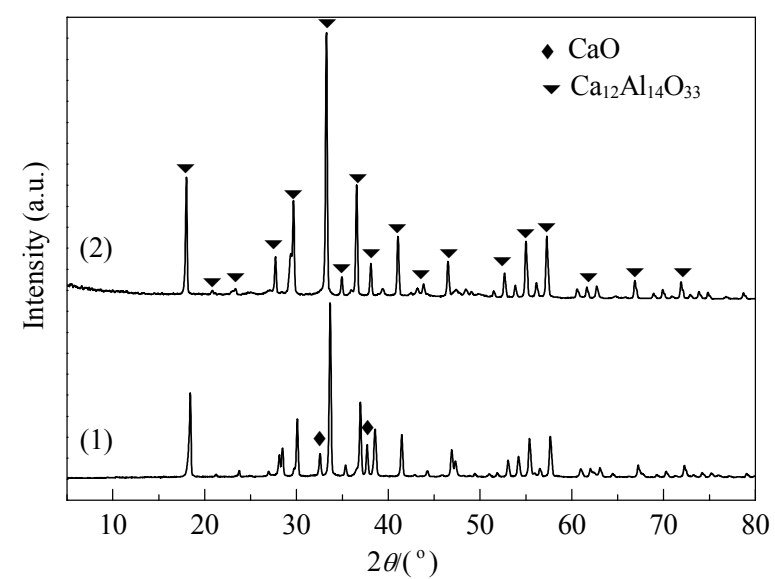

Fig. 9. XRD patterns of fresh calcined (1) and 6-times recycled (2) catalyst $\left(\mathrm{Ca}_{2} \mathrm{Al}\right)$. gave a high selectivity towards GC under mild conditions. The highest conversion of glycerol at $70{ }^{\circ} \mathrm{C}$ reached $93 \%$ with $97 \%$ selectivity to GC over the calcined hydrocalumite $\mathrm{Ca}_{2} \mathrm{Al}-800$. Characterization disclosed that $\mathrm{Ca}_{12} \mathrm{Al}_{14} \mathrm{O}_{33}$ was stable, but the $\mathrm{CaO}$ crystalline phase disappeared during recycle experiments and the leaching of $\mathrm{CaO}$ brought deactivation.

\section{References}

[1] Pagliaro M, Ciriminna R, Kimura H, Rossi M, Della Pina C. Angew Chem Int Ed, 2007, 46: 4434

[2] Zhou C H, Beltramini J N, Fan Y X, Lu G Q. Chem Soc Rev, 2008, 37: 527

[3] Bozell J J, Petersen G R. Green Chem, 2010, 12: 539

[4] Ide M S, Davis R J. Acc Chem Res, 2014, 47: 825

[5] Maris E P, Ketchie W C, Murayama M, Davis R J. J Catal, 2007, 251 : 281

[6] Vasiliadou E S, Eggenhuisen T M, Munnik P, de Jongh P E, de Jong K P, Lemonidou A A. Appl Catal B, 2014, 145: 108

[7] Nakagawa Y, Tomishige K. Catal Sci Technol, 2011, 1: 179

[8] Wang S, Liu H C. Catal Lett, 2007, 117: 62

[9] Maris E P, Davis R J.J Catal, 2007, 249: 328

[10] Huang Z W, Cui F, Kang H X, Chen J, Zhang X Z, Xia C G. Chem Mater, 2008, 20: 5090

[11] Zope B N, Hibbitts D D, Neurock M, Davis R J. Science, 2010, 330: 74

[12] Nie R F, Liang D, Shen L, Gao J, Chen P, Hou Z Y. Appl Catal B, 2012, 127: 212

[13] Liu S S, Sun K Q, Xu B Q. ACS Catal, 2014, 4: 2226

[14] Katryniok B, Paul S, Dumeignil F. ACS Catal, 2013, 3: 1819

[15] Chai S H, Wang H P, Liang Y, Xu B Q.J Catal, 2007, 250: 342

[16] Chai S H, Wang H P, Liang Y, Xu B Q. Green Chem, 2007, 9: 1130

[17] Takagaki A, Iwatani K, Nishimura S, Ebitani K. Green Chem, 2010, 12: 578

[18] Liu P, Derchi M, Hensen E J M. Appl Catal A, 2013, 467: 124

[19] Liu P, Derchi M, Hensen E J M. Appl Catal B, 2014, 144: 135

[20] Sonnati M O, Amigoni S, Taffin de Givenchy E P, Darmanin T, Choulet O, Guittard F. Green Chem, 2013, 15: 283

[21] Shaikh A A G, Sivaram S. Chem Rev, 1996, 96: 951

[22] Vieville C, Yoo J W, Pelet S, Mouloungui Z. Catal Lett, 1998, 56: 245

[23] Aresta M, Dibenedetto A, Nocito F, Pastore C. J Mol Catal A, 2006, 257: 149

[24] Hammond C, Lopez-Sanchez J A, Ab Rahim M H, Dimitratos N, Jenkins R L, Carley A F, He Q Kiely C J, Knight D W, Hutchings G J. Dalton Trans, 2011, 40: 3927

[25] Wang L G, Ma Y B, Wang Y, Liu S M, Deng Y Q. Catal Commun, 2011, 12: 1458

[26] Kim D W, Park K A, Kim M J, Kang D H, Yang J G, Park D W. Appl Catal A, 2014, 473: 31

[27] Zhang J, He D H. React Kinet, Mech Catal, 2014, 113: 375

[28] Jagadeeswaraiah K, Kumar C R, Prasad P S S, Loridant S, Lingaiah N. Appl Catal A, 2014, 469: 165

[29] Li H G, Gao D Z, Gao P, Wang F, Zhao N, Xiao F K, Wei W, Sun Y H. Catal Sci Technol, 2013, 3: 2801

[30] Zhang J, He D H.J Colloid Interf Sci, 2014, 419: 31

[31] Rokicki G, Rakoczy P, Parzuchowski P, Sobiecki M. Green Chem, 2005, 7: 529

[32] Ochoa-Gomez J R, Gomez-Jimenez-Aberasturi O, Maestro-Madurga B, Pesquera-Rodriguez A, Ramirez-Lopez C, Lorenzo-Ibarreta L, Torrecilla-Soria J, Villaran-Velasco M C. Appl Catal A, 2009, 366: 315 


\section{Graphical Abstract}

Chin. J. Catal., 2015, 36: 1759-1765 doi: 10.1016/S1872-2067(15)60915-9

\section{Transesterification of glycerol with dimethyl carbonate over calcined Ca-Al hydrocalumite}

Liping Zheng, Shuixin Xia, Xiuyang Lu, Zhaoyin Hou*

Zhejiang University

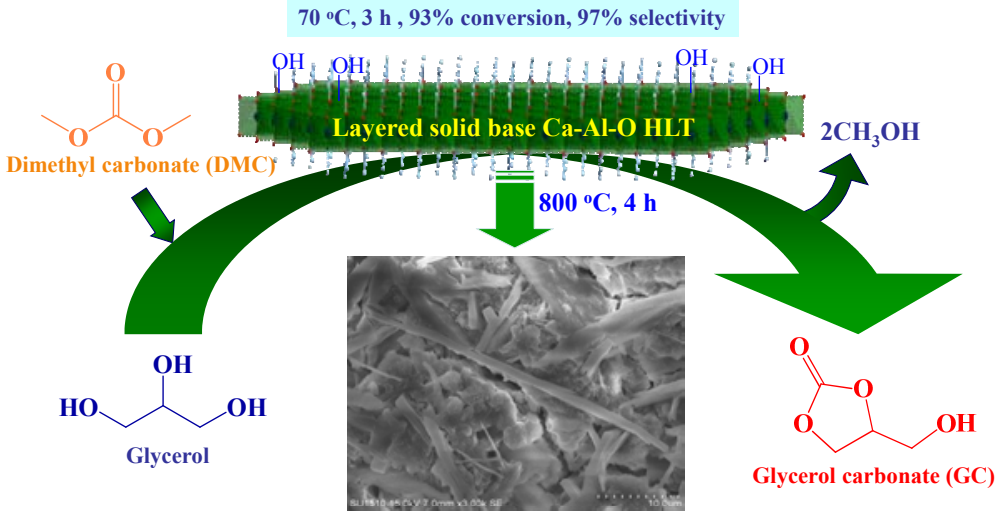

Calcined Ca-Al hydrocalumites are active and selective for the transesterification of glycerol with dimethyl carbonate, and the yield of glycerol carbonate reached $92 \%$ at $70^{\circ} \mathrm{C}$ and $3 \mathrm{~h}$.

[33] Algoufi Y T, Hameed B H. Fuel Process Technol, 2014, 126: 5

[34] Parameswaram G, Srinivas M, Hari Babu B, Sai Prasad P S, Lingaiah N. Catal Sci Technol, 2013, 3: 3242

[35] Malyaadri M, Jagadeeswaraiah K, Prasad P S S, Lingaiah N. Appl Catal A, 2011, 401: 153

[36] Zheng L P, Xia S X, Hou Z T, Zhang M Y, Hou Z Y. Chin J Catal (郑丽 萍, 夏水金金, 侯召同, 张梦媛, 侯昭胤. 催化学报), 2014, 35: 310

[37] Pan S Y, Zheng L P, Nie R F, Xia S X, Chen P, Hou Z Y. Chin J Catal (潘赛勇, 郑丽萍, 聂仁峰, 夏水金金, 陈平, 侯昭胤. 催化学报), 2012, 33: 1772

[38] Pfeiffer H, Ávalos-Rendón T, Lima E, Valente J S. J Environ Eng, 2011, 137: 1058

[39] Cavani F, Trifirò F, Vaccari A. Catal Today, 1991, 11: 173

[40] Chang P H, Lee T J, Chang Y P, Chen S Y. ChemSusChem, 2013, 6: 1076

[41] Gao L J, Teng G Y, Xiao G M, Wei R P. Biomass Bioenergy, 2010, 34: 1283

[42] Kuwahara Y, Tsuji K, Ohmichi T, Kamegawa T, Mori K, Yamashita
H. Catal Sci Technol, 2012, 2: 1842

[43] Zhou J Z, Xu Z P, Qiao S Z, Liu J Y, Liu Q, Xu Y F, Zhang J, Qian G R. Appl Clay Sci, 2011, 54: 196

[44] Wang Q, Gao Y S, Zhang Z, Duan L H, Umar A, O'Hare D. Sci Adv Mater, 2013, 5: 411

[45] Zhang P, Qian G R, Shi H S, Ruan X X, Yang J, Frost R L. J Colloid Interf Sci, 2012, 365: 110

[46] Lv T F, Ma W, Xin G, Wang R, Xu J, Liu D M, Liu F J, Pan D C. J Hazard Mater, 2012, 237-238: 121

[47] Zhang J, Xu Y F, Qian G R, Xu Z P, Chen C, Liu Q.J Phy Chem C, 2010, 114: 10768

[48] Alvarez M G, Segarra A M, Contreras S, Sueiras J E, Medina F, Figureueras F. Chem Eng J, 2010, 161: 340

[49] Yuan Z L, Wang L N, Wang J H, Xia S X, Chen P, Hou Z Y, Zheng X M. Appl Catal B, 2011, 101: 431

[50] Martavaltzi C S, Lemonidou A A. Ind Eng Chem Res, 2008, 47: 9537

[51] Simanjuntak F S H, Kim T K, Lee S D, Ahn B S, Kim H S, Lee H. Appl Catal A, 2011, 401: 220

\section{Ca-Al催化剂上甘油与碳酸二甲酯酯交换合成碳酸甘油酯 \\ 郑丽萍 ${ }^{\mathrm{a}}$, 夏水金金, 吕秀阳 ${ }^{\mathrm{b}}$, 侯昭胤 ${ }^{\mathrm{a}}{ }^{*}$ \\ a浙江大学化学系, 浙江省应用化学重点实验室, 浙江杭州 310028

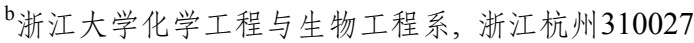

摘要: 生物柴油是一种环保、可再生、使用安全、可替代石化柴油的新型液体燃料, 其产量和使用范围正逐年扩大. 然而生物柴 油生产过程中的主要副产物甘油严重过剩, 因此甘油资源化转化和利用已经成为近年研究热点. 甘油可以作为一种平台化合物 实现向多种高附加值化学品的转化, 例如通过催化氢解合成 1,2 -丙二醇, 通过发酵和催化氧化制备二羟基丙酮, 通过脱水制备丙烯 醛和羟基丙酮, 通过酯交换反应生成甘油酯等. 其中, 以甘油为原料合成的碳酸甘油酯(GC)具有很好的工业应用前景. 以碳酸二 甲酯(DMC)为原料与甘油进行酯交换合成 $\mathrm{GC}$ 是近年内比较有工业发展潜力的合成路线. 前期研究发现, 固体碱对该反应具有很 好的催化活性, 而且随着催化剂碱性增强, 甘油转化率明显增加, 然而当催化剂(如 $\mathrm{NaOH}, \mathrm{KOH}$ 和 $\mathrm{K}_{2} \mathrm{CO}_{3}$ 等)碱性过强时, 产物选择 性明显降低. 水滑石类化合物是一种常见的碱性温和的固体催化剂, 而且其碱性与结构可以调节, 因此我们选择了一种常见水滑 石一一水铝钻石作为本研究的重点. 
本文通过共沉淀法制备了一系列不同 $\mathrm{Ca} / \mathrm{Al}$ 比(1-6)的Ca-Al水滑石, 并以此作为前驱体制备了新型的固体碱催化剂. XRD结 果表明, 当 $\mathrm{Ca} / \mathrm{Al}$ 比为 1-6时, 所有样品都出现了明显的水滑石特征衍射峰, 但当铝含量过高时会出现氢氧化铝杂相. SEM结果发 现, 当 $\mathrm{Ca} / \mathrm{Al}=2-4$ 时, 样品中水滑石的结晶度高, 有较完整的水滑石晶片, $\mathrm{Ca} / \mathrm{Al}=6$ 的样品中水滑石晶片较小, $\mathrm{Ca} / \mathrm{Al}=1$ 的样品中 有明显的无定形氧化铝杂相. TG-DSC 结果表明, $\mathrm{Ca} / \mathrm{Al}=2$ 的样品除了几个与水滑石相关的特征失重峰以外, 在 $7866^{\circ} \mathrm{C}$ 还检测到明 显的热吸收峰, 说明此时钻铝石已经发生分解, 生成了单独的 $\mathrm{Ca}_{12} \mathrm{Al}_{14} \mathrm{O}_{33}$ 晶相和氧化钻, 这与SEM结果一致. 这些水滑石经焙烧 后用于温和条件下催化甘油与DMC酯交换生成 $\mathrm{GC}$ 的反应, 发现上述催化剂对该反应具有很高的催化活性和目的产物选择性. 当 DMC 与甘油的摩尔比为 3 时, $70^{\circ} \mathrm{C}$ 反应 $3 \mathrm{~h}$ 后, 甘油转化率达到 $93 \%$, GC选择性高于 $97 \%$. 表征结果显示, 甘油转化率主要取决于焙 烧后 $\mathrm{Ca}-\mathrm{Al} 1$ 催化剂中强碱性中心数量. 其中经 $800{ }^{\circ} \mathrm{C}$ 焙烧后 $\mathrm{Ca} / \mathrm{Al}=2$ 的样品中强碱性中心数量最多, 因而表现出最高的催化活性. 焙烧后催化剂中形成的 $\mathrm{Ca}_{12} \mathrm{Al}_{14} \mathrm{O}_{33}$ 晶相在多次重复使用后仍可以稳定存在, 但是表面 $\mathrm{CaO}$ 易流失, 可能会降低催化剂的重复使用 活性.

关键词: 甘油; 碳酸二甲酯; 酯交换; 碳酸甘油酯; 钻铝水滑石

收稿日期: 2015-03-23. 接受日期: 2015-05-16. 出版日期: 2015-10-20.

*通讯联系人. 电话/传真: (0571)88273283; 电子信箱: zyhou@zju.edu.cn

基金来源：国家自然科学基金(21473155, 21273198, 21073159); 浙江省自然科学基金(LZ12B03001).

本文的英文电子版由Elsevier出版社在ScienceDirect上出版(http://www.sciencedirect.com/science/journal/18722067). 